\title{
PREŠEREN V GLASBI
}

Stefka Bulovec

Notno gradivo od 1846 do 1963 sem razdelila na tri oddelke: I. Glasbeni zborniki, II. Prešernove pesmi, III. Skladbe v proslavo Prešerna.

Glasbeni zborniki obsegajo samo uglasbene Prešernove pesmi. Obdelani so tako kot običajne knjige. Dodajam jim vsebino, poročila in ocene. Razvrščeni so v kronološkem redu.

Prešernove pesmi so urejene abecedno po naslovih ali pa po prvem verzu, kakor je to določil že Prešeren sam. Če je dal glasbenik svoji skladbi drugačen naslov, ga vodim kot kazalko. Pod naslovom pesmi so zbrani vsi skladatelji, ki so pesem glasbeno obdelali in vse skladbe nanjo. Navajam jih časovno po prvi objavi oziroma po času uglasbitve ter 
izpopolnjujem bibliografske podatke $s$ koncertnimi poročili in ocenami v kratkih povzetkih ter s ponatisi. Za tem priključujem isto tako kronološko razne priredbe, ki jih je bila skladba deležna. Vsaka prva objava in vsaka nova priredba predstavlja samostojno bibliografsko enoto $\mathrm{z}$ lastno tekočo številko, medtem ko so ponatisi vključeni v tekočo številko prve objave. Skoraj vse skladbe so izšle $v$ muzikalnih revijah in zbirkah. Zato jih popisujem kot časopisne članke, t. j. specialno muzikalnim podatkom dodajam naslov, letnico, leto, zvezek in strani revije ali zbirke. Pri rokopisnih notah je navedeno tudi hranilišče.

Nekaj skladb nisem mogla preveriti, ker imamo o njih samo literarna poročila. Nekatere namreč niso bile ne napisane ne natisnjene; druge so na koncertih sicer peli, a not ne poznamo; tretje so bile nekoč znane, a so medtem propadle. O usodi vsake od teh neznank poročajo bibliografske pripombe.

Tudi tretji oddelek - Skladbe $v$ proslavo Prešerna - je urejen kronološko, skladbe pa so obravnavane po že navedenih bibliografskih prijemih.

Bibliografija naj bi bila zaključena $\mathrm{z}$ imenskim kazalom skladateljev, prirediteljev, poročevalcev in ocenjevalcev, pevcev in prevajalcev, a je zaradi tesnega prostora moralo odpasti.

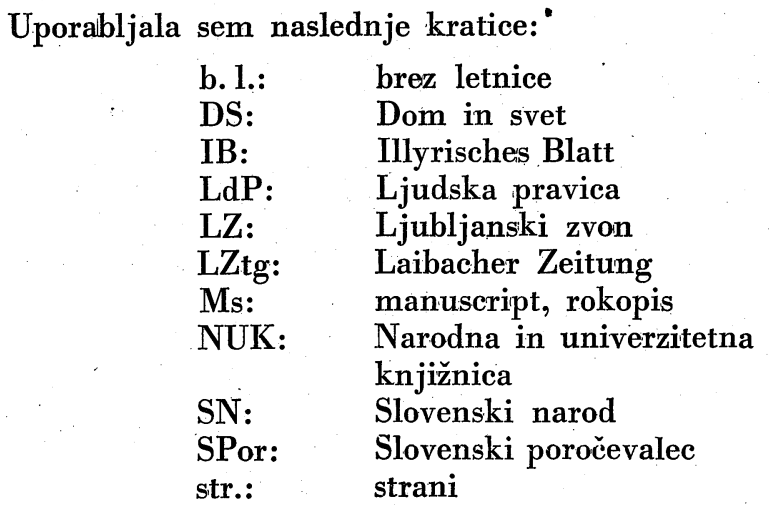

Za kontrolo muzikalnega gradiva iz prejšnjega stoletja mi je bil dragoceno pomagalo bibliografski seznam s temo »Prešernova pesem in naši skladatelji«, ki ga je objavil Fran Gerbič v LZ 1. 1900, str. 865868. Notni material sem zbirala po naših bibliotekah. S pretežno večino mi je postregla glasbena zbirka Narodne in univerzitetne knjižnice, dopolnila sem dobila tudi $v$ knjižnici Glasbene akademije in arhivu Slovenske filharmonije. Zaradi nekaterih rokopisov in raznih drugih podatkov sem se obračala osebno in pismeno do skladateljev samih. Vsi navedeni so mi z razumevanjem in prijazno postregli, za kar se jim iskreno zahvaljujem, kakor tudi glasbenemu zgodovinarju Rafaelu Ajlecu, ki me je opozoril na devet uglasbenih pesmi, ki jih hranijo avtorji sami in so le redkokomu znane. 


\section{GLASBENI ZBORNIKI}

Slovenska gerlica. Venec slovenskih pesem Dr. Fr. Prešern-a. Napevi od Kamilo Mašek-a. Peti zvezek. V Ljubljani. Natis in kamnotiskarnica Jožefa Blaznika 1859. 23 str. $13,5 \times 20,5 \mathrm{~cm}$.

V s e bi n a : 1. Strunam, 2. Dekletam, 3 a in 3 b. Pod oknom, 4. Prošnja, 5. Kam?, 6. Ukazi, 7. K slovesu, 8. Sila spominja.

Slovenska gerlica. Venec slovenskih pesem Dr. Fr. Prešern-a. Napevi od Kamilo Mašek-a. Šesti zvezek. V Ljubljani. Natis iz kamnotiskarnice Jožefa Blaznika 1859, 23 str. $13,5 \times 20,5 \mathrm{~cm}$.

V s e bi n a : 9. Zgubljena vera, 10. Mornar, 11a in 11 b. Soldaška, 12. V spominj Valentina Vodnika, 13. V spominj Andreja Smoleta, 14. Od železne ceste, 15. Zapuščena, 16. Nezakonska mati. - P o ročila in o c e ne : Pavel Kozina, Življenje in svet 10/1931 str. 712-717, monografija zvezkov I-VIII. - Dragotin Cvetko: Davorin Jenko 1955, str. 62-64, vrednotenje Maškovih skladb na Prešernova besedila $v 5$, in 6 . zvezku.

Davorin Jenko: Dr. Prešernove pesmi za petje in glasovir. Op. 3. Vienne. Chez Gustav Albrecht Editeur 1862, (II) +11 str. $4^{0}$.

$\mathrm{S}$ posvetilom: Prevzvišenemu gospodu Vil. Balabinu, ruskemu poslancu. V sebina : 1. Kam?, 2. Zdravljica, 3. K slovesu, 4. Strunam, 5. Mornar. P o r o či l a i n o c e n e : Slovenski glasnik 1863, str. 28, oglas. - Dragotin Cvetko : Davorin Jenko 1955, str. 61-64, vrednotenje skladb.

Davorin Jenko: Samospevi z glasovirom. V Ljubljani. Založila ljubljanska čitalnica. Tisk Blaznikov [1880], (10) str., $4^{0}$.

V s e bi n a : Kam?, Zdravljica, K slovesu, Strunam, Mornar.

Josip Michl: Štiri Prešernove pesmi. V Ljubljani. Glasbena matica 1921, 20 str., $4^{0}$.

V sebina : 1. Nezakonska mati, 2. - da jo ljubim, Iz Gazel, 3. Pevcu, 4. Napis na velikem zvonu pri Sv. Joštu. - Poročila in o c e n e : [Emil Adamič $]$-č., SN 54/1921 (4. 11.), št. 248, str. 5, graja skladateljeve neprimerne pripombe. - V[adimir] L[ovec], LdP 11/1950, (9. 12.), št. 293, str. 3, o odlikah skladb.

Lavoslav Pahor: Dve Prešernovi pesmi za simfonični orkester. 1923, 4 str., $4^{0} .6$

Rokopis je v knjižnici Akademije za glasbo sign. I a-80. Koračnica, v kateri je uporabljena Maškova melodija »Strunam» za prvo temo, za trio pa Kocijančičev napev pesmi »Kam?«.

Prešernov dan, naš kulturni praznik. Članki. Izbor pesmi. Napevi. Ljubljana. Slovenski knjižni zavod 1946, III. del: Napevi str. 35-44, V. $8^{0}$.

Izšla je tudi hrvatska izdaja (str. 45-53). - V s e bi n a : Zdravljica, Strunam, Pod oknom, Soldaška (Šivičev in Maškov napev), Zapuščena, Zdravljica (Premrl). $\mathrm{V}, \mathbf{8}^{0}$.

Sedem Prešernovih pesmi. Ljubljana. Državna založba Slovenije 1948, (12) str.,

Ponatis iz knjige: Prešernov dan, naš kulturni praznik.

Pet Prešernovih pesmi. Izbor samospevov. (Ob stoletnici Franceta Prešerna izdala Državna založba Slovenije v redakciji Antona Lajovica in Dragotina Cvetka) 1949, 24 str., $4^{0}$.

V s e bi n a : Strunam, Kam?, Nezakonska mati, Mornar, - da jo ljubim.

Breda Šček: Oj Vrba. Pet pesmi za glas in klavir. Besedilo dr. Fr. Prešerna.

1. Pod oknom, 2. Sonet nesreče, 3. Ribič, 4. Vso srečo ti želim, 5. K slovesu. Ljubljana, opalografija 1954, 20 str., $4^{0}$. 


\section{POSAMEZNE PESMI}

Barkarola. Glej: Ribič. Risto Savin.

— da jo ljubim. Glej: „Žalostna, komu neznana je resnicac. Josip Michl.

Dekletom

K a mi l o M a š ek, glas, klavir, besedilo. - Slovenska gerlica V/1859, str. $6-7$.

M a ti j a Tom c, moški zbor, besedilo. 1945, 3 str., $4^{0}$. Rokopis je last avtorja.

R a d ov a n G o bec, mladinski zbor, besedilo. Ljubljana, opalografija 1955, 2 str., $4^{0}$.

Dohtar. Glej: Danilo Švara: Slovo od mladosti. Opera »Prešeren«.

Elegija svojim rojakom

Peter Bitenc, mladinski zbor, besedilo. Ljubljana, opalografija 1955, 2 str., $4^{0}$.

M a rija n Li povšek, mladinski zbor in predelano v mešani zbor, besedilo. 1956, 3 str., $4^{0}$. Rokopis je last avtorja.

Epigram. Glej: Prešernova vera. L. M. Škerjanc.

Gazele

G a šp a $\mathbf{r}$ a š e k, melodramske deklamacije, moški zbor, klavir, besedilo. (60) str., $4^{0}$.

Priloženo pismo z dne 13. 12. 1870, (3) str. - Rokopis v NUK glasbena zbirka. - Ocena: Dragotin Cvetko: Zgodovina glasbene umetnosti na Slovenskem III/1960, str. 84, 109.

Lucijan Marija Skerjanc: Gazele. Sedem orkestralnih pesnitev. Ghasels. Sept poèmes pour orchestre. Partitura-Partition. Ljubljana. Slovenska akademija znanosti in umetnosti 1957. (IV) +87 str., V. 20. (Dela SAZU, razred za umetnosti 13. Serija za glasbeno umetnost 13.)

Poročila: L. M. Skerjanec, Radio Slovenija 1/1951, št. 2, str. 4-5, nastale med 12. 2. in 17. 5. 1950. Povezava njegovih gazel s Prešernovimi je zgolj zunanja. - Koncertni list 10/1960-61, str. 95-96.

Glosa

E mil Ada mič, kanon za 1. in 2. sopran, 1. in 2. alt, besedilo prve in druge vrstice motiva. - E. Adamič: Dva kanona za štiri glasove, kanon št. 2. Rokopis NUK, glasbena zbirka. - Album za mlade pevce. III. stopnja. 1931, št. 10. Note neznane.

Poročilo: Slavko Koželj v knjigi L. M. Škerjanca: Emil Adamič 1937, str. 178, št. 804, album je bil pripravljen za tisk v ediciji Glasbene matice.

Godec. Glej: Žienska zvestoba.

Gondoljera. Glej: Lepa Vida. Karel Jeraj.

Hčere svet

J a n e z T o m a ž e ve c, Tomažovic, Tomaževic, Tomažič. Note neznane. 19

Poročilo: Leopold Kordesch, IB 1848 (11. 7.), Nr. 56, str. 224, pesem so peli v deželnem gledališču 8. 7. 1848, napev ni ugajal, ker je bil preveč modern in izumetničen. - Janez Bleiweis, Novice 6/1848 (19. 7), list 29, str. 125-126, pesem je pel Ilirski kor in ni ugajala. - Anton Trstenjak: Slovensko gledališče 1892, str. 37-38, peli so Tomažičevo pesem. - Dragotin Cvetko: Zgodovina glasbene umetnosti na Slovenskem II/1959, str. 374-375, III/1960, str. 83-84, komentar $\mathrm{k}$ neznani skladbi in določitev skladateljevega imena. 
B l a ž A r n i č, sopran solo, klavir, besedilo. 1928, 5 str., $4^{0}$. zgubila.

Rokopis je last avtorja. To je prvi koncept. Predelava se je med okupacijo

M i a e l Rož a n c, moški zbor, bas solo, besedilo. - Zbori 9/1933, str. $17-20$, št. 3 a.

Himna. Glej: Zdravljica. Vasilij Mirk.

Izgubljena vera. Glej: Zgubljena vera.

K slovesu

K a mi l o M a š e k, glas, klavir, besedilo. - Slovenska gerlica V/1859, str. $20-21$, št. 7 .

Poročilo: Gojmir Krek, Novi akordi, glasbenoknjiž. pril. 12/1913, str. 33, napev »pleše nekak bolero«.

Davorin Jenko, petje, klavir, besedilo. - D. Jenko: Fr. Prešernove pesmi za petje in glasovir 1862, str. 7, št. 3. Knjižnica Glasbene akademije II-812. - D. Jenko: Samospevi z glasovirom [1880], št. 3. - D. Jenko: 18 slovenskih pesnij [1908], str. 5 .

B e n j a m i I p a vec, glas, klavir, besedilo. - B. Ipavec: Pesmi 1865, str. $39-42$.

H rabroslav Volarič : Za slovo. Četverospev, moški zbor, besedilo. Kobarid 19. 5. 1884, 4 str., $8^{0}$.

Rokopis NUK, glasbena zbirka 2805/54.

Fra n Ge r bi č, glas, klavir, besedilo. [b. l.] 4 str., $4^{0}$. 26

Rokopis NUK, glasbena zbirka 3190/54.

Fra n ce Ma rolt, mešani zbor, brsedilo. - NUK Ms Glasbena zbirka. 27

B r ed a Š ě e k, glas, klavir, besedilo. - B. Šček: $O j$ Vrba; str. 18-20, št. 5 .

St a n k P P e m r 1, bariton, klavir, besedilo. - Slovenska glaśbena revija 4/1956, št. 1, str. 1-4.

Poročilo: [Marijan Lipovšek], Slovenska glasbena revija, glasbenoknjiž. pril. 4/1956, št. 1, ov. str. III. vrednotenje skladbe.

Kam?

K a m i lo M a šek, petje, klavir, besedilo. - Slovenska gerlica V/1859, str. $14-16$, št. 5 .

Poročila: Anton Trstenjak: Slovensko gledališče 1892, str. 113, o predvajanju v ljubljanskem gledališču 1. 12. 1870. - Vilko Ukmar, Zbornik slovenskih samospevov I/1953, str. 5-6, o prekomponirani pesmi.

Davorin Jenko, petje, klavir, besedilo. - D. Jenko: Fr. Prešernove pesmi za petje in glasovir 1862, str. 3-5, št. 1. - D. Jenko: Samospevi z glasovirom [1880], št. 1. - D. Jenko: 18 slovenskih pesnij [1908], str. 8-9. - Pet Prešernovih pesmi 1949, str. 7-8.

Poročila: Stanko Premrl, DS 23/1910, str. 556. Jenko je zložil napev leta 1860 na Dunaju. O koncertu Glasbene matice v Ljubljani 6. 11.1910 ob 50-letnici Jenkovega »Naprejađ, kjer je skladbo zapel Ljubiša Iličić. - Jutro 1/1910 (7. 11.), št. 249, str. 2, o istem koncertu. - Emil Adamič, Novi akordi, glasbeno knjiž. pril. 10/1911, št. 3, str. 37. O koncertu podružnice Glasbene matice v Trstu 1. 4. 1911 ob 50-letnici Jenkovega »Naprejac, kjer je skladbo zapel tenorist Stefan Sink. [Marko-Bajuk] B., Slovenec 38/1910 (7. 11.), št. 352, str. 2, o tujem značaju skladbe.

K o c i j a n č i č J o si p, tenori, basi, besedilo. - J. Kocijančič: Slovenske narodne pesmi nabral za moški zbor $\mathrm{I}[1876]$, str. 11, št. 12. 


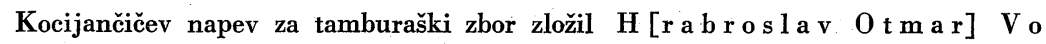
g r i č. - Slavjanska lira I/1900, str. 85-86, št. 1. 33

Kocijančičev napev za citre priredil I va $\mathrm{Kiferle.-1.} \mathrm{Kiferle:} \mathrm{Slo-}$ venske narodne pesmi za citre in petje VIII/1917, št. 10, 2. izdaja 1920, št. 10 . 34

Kocijančičev napev je uporabil za trio v koračnici Levoslav Pahor. L. Pahor: Dve Prešernovi pesmi za simfonični orkester 1923, 2 str., $4^{0}$. 35

Rokopis v knjižnici Akademije za glasbo I a-80.

B e $\mathbf{n} \mathbf{j}$ a $\mathbf{m}$ i n I pave c, glas, klavir, besedilo. - B. Ipavec: Slovenske pesmi 1877, zv. I, str. 3-5. 36

Ocena: Vilko Ukmar, Zbornik slovenskih samospevov I/1953, str. 6 .

Anton $\mathrm{H}$ a j d rih, bariton solo. 26. 11. 1878.

Poročila: Fran Rákuša: Slovensko petje 1890, str. 70, rokopis je v skladateljevi zapuščini. - Emil Adamič, Novi akordi, glasbeno knjiž. pril. 11/1912, str. 39, samospev je slab in dvomi, da bi bil Hajdrihov. Valentin Kosovel je priredil samospevu spremljavo in rokopis izročil leta 1911 tržaški podružnici Glasbene matice. Po izjavi Viktorja Šnca in Vasilija Mirka je Hajdrihova zapuščina ob požaru tržaškega Narodnega doma (kjer je bila shranjena) propadla. Note niso znane.

B e $\mathbf{n}$ j a m i n I p a v e c, moški zbor, četverospev, bariton solo. Uglasbil in Slavjanskemu pevskemu društvu u Beču posvetil B. Ipavec. V Gradcu 1881, 4 str., $4^{0}$.

Rokopis v NUK, glasbena zbirka 2523/54.

Fran S. Vilh ar, bariton, klavir, besedilo. - F. S. Vilhar: Skladbe I[1883], str. 10-11, enako hrvatska izdaja. - Djulabije I. zv. str. 11-13 br. 2. Djulabije, konzervatorijska izdaja zv. I, str. 9-11, br. 2. - Zbornik slovenskih samospevov II/1953, str. 28-30.

Ocene: Vojteh Valenta, Kres 4/1884, str. 270, hvali melodično lepoto samospeva in karakteristično spremljavo klavirja. - Danilo Fajgelj. LZ 4/1884, str. 183, hvali živahnost in ogenj kompozicije. - Vilko Ukmar, Zbornik slovenskih samospevov I/1953, str. 6, III/1953, str. 19, o dramatičnem zanosu napeva.

S a š a Š a n t e 1, glas, klavir, besedilo. 1905, 4 str., $4^{0}$. NUK Ms, glasbena zbirka 2444/55.

F r a n G e r b i č, glas, klavir, besedilo. Op. 54, št. 1. - Novi akordi 12/1913, str. 45-47. - Zbornik slovenskih samospevov II/1953, str. 54-58. 41

Ocene: Stanko Premrl, DS 27/1914, str. 130. — [Pavel] Kozina, LZ 34/1914, str. 343. - [Gojmir Krek], Novi akordi, glasbeno knjiž. pril, 12/1913, str. 57. Vilko Ukmar, Zbornik slovenskih samospevov I/1953, str. 6, II/1953, str. 49, o dramatičnih elementih samospeva.

Gerbičev napev za glas ali trombo in orkester priredil Filip B e r nard.

Partitura. Ljubljana 4. 2. 1938, 11 str. + glas + note za 19 glasbil., $4^{0}$.

Rokopis $\mathrm{v}$ arhivu Slovenske filharmonije 193.

Fran Venturini, moški zbor, besedilo. - F. Venturini: Šest mešanih in moških zborov, Trst 1923, str. 8-10.

Da n i lo Šr a ra. Glej: Slovo od mladosti. Opera »Prešeren“.

A n ton Jobst, moški zbor, besedilo. - NUK Ms Glasbena zbirka.

Krst pri Savici

Josipin a T u r nograjska: Črtomir in Bogomila. Spevoigra.

Poročilo: Lovro Toman, Novice 12/1854, str. 274; Novi akordi, glasbeno knjiž. pril. 13/1914, str. 22 . O spevoigri je skladateljica mnogo govorila, več pesmi iz nje prepevala, a not ni zapisala.

Anton Hajdrih : „O sem, na srce moje, Bogomila.đ Tenor, klavir. -

Orkestriral $S$ a ša $\breve{S}$ a $\dot{n}$ te $l$. 
Note neznane. - Poročila: Vojteh Valenta, SN 9/1876 (3. 12.), št. 278, str. 1-3. - Fran Gerbič, LZ 20/1900, str. 867-868. Pesem je pel Ivan Meden na koncertu ljubljanske čitalnice.

S l a v k o O s t e r c, simfonična slika, partitura. [1920], 24. str., $4^{0}$. 47

Rokopis NUK, glasbena zbirka 1890/49.

S l avk o O ste r c, note za 16 glasbil. [1920], $4^{0}$.

Rokopis $v$ arhivu Slovenske filharmonije 865.

S lavko Osterc, glasbena drama v treh dejanjih po Prešernovi pesnitvi. 9. 8. 1921. Klavir s tekstom 154 str., $4^{0}$. Glasovi pevskih vlog $48+8$ str., $4^{0}$. Ms NUK, glasbena zbirka 2642, 2643/53.

Besedilo drame priredil Slavko Osterc, popravil Gustav Silih. 21 str., $8^{0}$. Ms NUK, glasbena zbirka. - Ocene: D[anilo] P[okorn], Radio Slovenija 1/1951, št. 4, str. 11. - Marijan Lipovšek, Slovenska glasbena revija, glasbeno knjiž. pril. 1/1951-52, str. 44 .

M a tij a T o m c, partitura za soli, moški, ženski in mešani zbor ter simfonični orkester. 1945-47, 342 str., $4^{0}$.

Rokopis je last skladatelja. - Libreto: Z uporabo Prešernovih verzov prirejeno besedilo za opero $\mathrm{v}$ petih dejanjih priredil Zorko Simčič. 48 strojepisnih strani, $8^{0}$. Rokopis last Matije Tomca. - [Zorko Simčič] Bine Šlinov: Krst pri Savici. Igra v petih slikah. Buenos Aires. Katoliški misijoni $1953,44+$ (III) str. $8^{0}$. Odlomek libreta je prvič objavil Slovenčev koledar 1944, str. 165-168.

Vasilij. Mirk, simfonična slika, mešani zbor. Vizija I.: „Največ sveta otrokom sliši Slave«. 3. 10. 1959.

Rokopis je še nedokončan, last skladatelja.

Lepa Vidia

K a r e l J e r a j, melodramska skladba. Partitura za simfonični orkester. Besedilo [b. 1.] 44 str. $4^{0}$. Rokopis.

K a r e l J e ra j, melodrama z velikim orkestrom. Priredba za klavir. Ljubljana, Glasbena matica, edicija št. 263. Opalografiral Mihael Kunaver 1944, 11 str. + skladateljeva slika, $4^{0}$.

Karel Jeraj: Gondoljera iz melodrame. Za godalni orkester. Note za pet godal, $4^{0}$.

Rokopis v arhivu Slovenske filharmonije 310 .

K a r e l J e r a j , Gondoljera. Klavir. - Novi akordi 1/1901-1902, str. 69-71.

Zorko Prelovec, narodna balada za solo, mešani zbor in orkester. Ob petletnici »Strune« uglasbil Z. Prelovec. Orkestralna partitura 23. 7. 1907, 47 str., $4^{0}$.

Rokopis bil leta 1947 last avtorja.

Z orko Prelovec, zbor in klavir 12 str., soprani, alti, tenori, basi, klavir à 4 str.; sopran solo 2 str., alt solo 1 str., bariton solo 1 str.; note za devet glasbil. 6. 7. $1907,4^{0}$.

Rokopis bil leta 1947 last avtorja.

Zorko Prelovec, zborovski part (mešani in moški zbor, sopran, alt, bariton solo) tiskani 1936, 8 str., $4^{0}$.

Ma r ja n Kozin a, mešani zbor, sopran in bas solo. Ljubljana. Opalografija 1946, 11 str., $4^{0}$. Ponatis 1951, 11 str., $4^{0}$.

Vilko U k m a r, balet. Simfonični orkester, mešani zbor. Partitura, 1956, 200 str., $4^{0}$.

Rokopis je last skladatelja. Poleg narodne balade je skladatelja inspirirala tudi Prešernova balada.

V i 1 k o U k m a r, mešani zbor. Ijubljana. Opalografija 1957, 7 str., $4^{0}$. 
"Luna sije«. Glej: Pod oknom.

Magistrale

Danilo Švara : „Ti si življenja moj'ga magistrale.« Glas, klavir, besedilo. - D. Švara: Trije spevi iz opere »Prešeren« za tenor in klavir. Ljubljana 1954, str. 9-11.

"Mars'kteri romar«

Lucijan Marija Skerjanc: Sonet za glas in klavir basistu Juliju Betettu. Ljubljana, Glasbena matica, edicija št. 241, 1943, 4 str., $4^{0}$.

L u cija n Marija Skerjanc: Sonet. (Matevžu Langusu.) Glas in orkester. Priredil 7. 5. 1946. Partitura 9 str., note za 15 glasbil, $4^{0}$.

Rokopis je $\mathrm{v}$ knjižnici Glasbene akademije $\mathrm{I}$ a-134.

L u cijan Marija Škerjan c : Sonet. Glas in klavir. - L. M. Škerjanc: Samospevi za glas in klavir III/1957, str. 46-48.

Mati. Glej: Nezakonska mati. Slavko Osterc.

Memento mori

B l a ž A rni č, simfonična pesnitev. Ljubljana 1934, 28 str., $4{ }^{9}$.

Rokopis je last skladatelja. - Ocene: S[rečko] K[umar], Jutro 16/1935 (21. 11.), št. 270, str. 7. - [Fran Kimovec] K., Slovenec 63/1935 (26. 11.), št. 272 , str. 5 , analiza skladbe in poročilo o orgelskem koncertu $\mathrm{v}$ Ljubljani 19. 11. 1935.

Stanko Prem r l, glas, klavir, besedilo. - St. Premrl: Trije samospevi za nižji glas s klavirjem 1938, str. 3-6. - Slovenska glasbena revija 1/1951-52, str. 24-27.

Ocene: Marijan Lipovšek, Slovenska glasbena revija, glasbenoknjiž. pril. 1/1951-52, str. 57-58. - Vilko Ukmar, Zbornik slovenskih samospevov I/1953, str. 4, primer samospeva razmišljujočega značaja.

Slavko Mihelčič, moški glas (bas), klavir, besedilo. Ljubljana 1945, 5 str., $4^{0}$.

Rokopis hrani operni pevec Ladko Korošec.

"Moj bron je najden bilk

Josip Michl: Napis na velikem zvonu pri Sv. Joštu. Fragment za močan bas, pri katerem klavirski spremljevalec vljudno prevzame nalogo zvonikarjevo. J. Michl: Štiri Prešernove pesmi 1921, str. 17-19.

Ocena: V[ladimir] L[ovec], LdP 11/1950 (9. 12.), št. 293, str. 3. »Štirivrstični napis prav gotovo ne bi mogel služiti kot besedilo za romantični samospev, če mu skladatelj ne bi dal bujnega ozadja s posnemanjem zvonov.«

P e ter Li p a r, bariton solo, moški zbor, besedilo. 1952. - NUK Ms, Glasbena zbirka.

Mornar

J u rij Fleišman, glas, klavir, besedilo, - Slovenska gerlica 2/1848, str. $6-7$; drugi natis 1852 , str. $6-7$; nova izdaja $2 / 1864$, str. $6-7$.

Poročila in ocene: Leopold Kordesch, IB 1848 (3. 6.), Nr. 45, str. 180, (17. 6.) Nr. 47, str. 196. O predvajanju pesmi na koncertu Slovenskega društva 30. 5. 1848. - [Janez Bleiweis] B., Novice 6/1848 (7. 6.), list 23, str. 96. O neuspelem predvajanju na prvem slovenskem koncertu (besedi) v ljubljanskem gledališču. - Vlado Golob, Slovenska glasbena revija, glasbenoknjiž. pril. 2/1953-54. O kričečem nesorazmerju med Prešernovim besedilom in glasbo. $O$ njeni priljubljenosti med kmečkimi fanti.

Philipp Jacob Rechfeld. Note neznane. 
Poročila: IB 1849 (13. 1.), Nr. 4, str. 16. Pesem so peli na besedi Slovenskega društva 1. 1. 18499. - Fran Gerbič, LZ 20/1900, str. 868. Pela jo je Rechfeldova na besedi v Virantovih prostorih. - Dragotin Cvetko: Zgodovina glasbene umetnosti na Slovenskem III/1960, str. 87. Komentar k neznanemu glasbenemu delu.

K a mi lo M a š ek, glas, klavir, besedilo. - Slovenska gerlica VI/1859, str. $4-5$, št. Io.

Ocena: Vilko Ukmar, Zbornik slovenskih samospevov 1/1953, str. 5. O kitični kompoziciji.

K a mi lo M a š e k, moški zbor, besedilo. - [Dvainštirideset pesmi b. 1.], str. $27-28$, št. 20.

Rokopis NUK, glasbena zbirka 2549/55.

Davorin J enko, petje, klavir, besedilo. - D. Jenko: Fr. Prešernove pesmi 1862, str. 10-11, št. 5. Hrani knjižnica Glasbene akademije II-812. - D. Jenko: Samospevi z glasovirom [1880], str. (9-10), št. 5. - D. Jenko: 18 slovenskih pesnij [1908], str. 6-7.

Poročilo: Fran Rákuša: Slovensko petje 1890, str. 158. Pesem so peli prvikrat javno v dvorani »Zum goldenen Zeisig« na Dunaju v začetku leta 1860.

L e opold Ledenik, kvartet. Note neznane.

Poročila: LZtg 186万 (4. 12.), Nr. 378, str. 1113. Pesem so peli z velikim uspehom na Prešernovi slavnosti 2. 12. 1865 v slovenskem gledališču. - Novice 23/1865 (6. 12.), list 49, str. 402. Pel jo je Fran Vidic. - Fran Vidic, LZ 20/1900, str. 834, poroča, da je skladba kvartet. - Dragotin Cvetko: Zgodovina glasbene umetnosti na Slovenskem III/1960, str. 87. Nastanek neznanega dela okrog 1. $1848-1850$.

Avgust Armin Leban, moški zbor, bariton solo, besedilo. - A. Leban: Glasi Primorja. Uredil Janko Leban. I[1879], (str. 9-12), št. 4.

Začetek besedila: „Le jadra spet napnimoঞ. - Ocena: Fran Rákuša: Slovensko petje 1890, str. 82. Skladba ima glasbeno dovršeno obliko in več duha nego druge pesmi drugih skladateljev.

Avgust Armin Leban : Mornar - Der Seemann. Bariton solo, moški zbor, klavir, besedilo (slovensko in nemški prevod). Note neznane.

Poročilo: Fran Gerbič, LZ 20/1900, str. 868. V Gerbičevem času je hranil note arhiv Glasbene matice.

Avgust Armin Leban, madinski zbor, klavir, besedilo. - H[inko] Druzovič : Lira, srednješolska pesmarica II/1912, str. 86-93.

Fran S. Vilhar: Mornar. Pesem za niži glas. Op. 66. Ljubljana, Glasbena matica 1882,11 str., $4^{0}$.

Franc S. Vilh a r, bariton, klavir, besedilo. - F. S. Vilhar: Skladbe I[1883], str. 5-9. Enako v hrvatski izdaji. - Djulabije zv. I, str. 5-10, št. 1. Djulabije, br. 70, konzervatorijska izdaja zv. I, str. 3-8, št. 1. - Pet Prešernovih pesmi 1949, str. 13-18. - Zbornik slovenskih samospevov II/1953, str. 21-27. 81

Ocene: M., Kres $3 / 1883$, str. 117, analiza skladbe, ki jo prišteva $k$ najboljšim svoje vrste. - Vojteh Valenta, Kres 4/1884, str. 270 o melodični lepoti in dramatičnem patosu samospeva. - Danilo Fajgelj, LZ 4/1884, str. 182-183, o ognjeviti fantaziji skladbe. - Robert Bežek, SN 16/1883 (15. 1.), št. 11, str. 2-3, (16. 11.) št. 263, str. 1, analiza skladbe. - Vilko Ukmar, Zbornik slovenskih samospevov I/1953, str. 19, o dramatičnosti samospeva.

Vilharjev napev za tamburaški zbor priredil $H[\mathrm{rabros} l a v$ tmar $] \mathrm{Vo} \cdot$ g r i č. Slavjanska lira 1/1900, str. 91-92, št. 7, fragment. $\quad 82$

Vilharjev napev za citre priredil Ivan Kiferle. - I. Kiferle: Venec jugoslovanskih pesmi za citre in petje 1930, str. 19-23, št. $10 . \quad 83$

Vilharjev napev za glas in simfonični orkester instrumentiral $L$ u cijan $M$ ari j a $\mathrm{S}$ kerja n c. Partitura in orkestralni glasovi. Ljubljana 6. 8. 1930. Rokopis 
v arhivu Slovenske filharmonije 357. - Partitura 1934, 21 str., $4^{0}$. Ms NUK, glasbena zbirka $1773 / 49$.

M a rk o B uj a k, četveroglasni zbor [narodni napev]. - M. Bujak: Slovenske narodne pesmi. Ljubljana. I. zvezek, drugi natis 1904, str. 42-43, št. 24. IV. zvezek 1904, str. 42-43, št. 24 (ta zvezek je del naklade I. zvezka). - I. zvezek, pomnožena izdaja [1925], str. 42-43, št. 24.

M a rk o B a j u k, [narodni napev] iz Thana. Moški zbor, besedilo. - M. Bajuk: Slovenske narodne pesmi za moški in mešani zbor. Ljubljana 1927, zviezek V, str. 26-27, št. 21.

Ferdinand Karl "Füchs : Brodnik. Samospev (sopran), klavir. Note neznane.

Poročilo: Dragotin Cvetko: Zgodovina glasbene umetnosti na Slovenskem III/1960, str. 42, 87, komentar $k$ neznanemu glasbenemu delu.

Napis na velikem zvonu pri Sv. Joštu. Glej: „Moj bron je najèdn bil.đ

Napitnica. Glej: Zdravljica. Benjamin Ipavec.

Nezakonska mati

K a m i lo Ma š ek, petje, klavir, besedilo. - Slovenska gerlica VI/1859, str. $20-23$, št. 16 .

Fra n S. Vil h a r, sopran, klavir, besedilo. - F. S. Vilhar: Skladbe I[1883], str. 19-22. Enako v hrvatski izdaji. - Djulabije zv. I, str. 19-23, št. 5 (Op. 124.) - Djulabije br. 70, konzervatorijska izdaja, zvezek I, str. 17-21, št. 5. - Zbornik slovenskih samospevov II/1953, str. 31-36.

Ocene: Vojteh Valenta, Kres 4/1884, str. 270, o melodični lepoti, dramatičnem patosu in karakteristični spremljavi klavirja. - Danilo Fajgelj, LZ 4/1884, str. 183, biser samospevov. - Lucila Podgornik, Slovan 2/1885, str. 250-251, o menjajočem izrazu. - Robert Bežek, SN 16/1883 (16. 11.), št. 263, str. 1-2, o skrbni izdelavi. - Vilko Ukmar, Zbornik slovenskih samospevov I/1953, str. 6, II/1953, str. 19, izliv melanholičnosti.

Vilharjev napev za tamburaški zbor priredil $\mathrm{H}[\mathrm{rabroslav} O \mathrm{tmar}] \mathrm{Vo}$. g r i č. Slavjanska lira $1 / 1900$, str. 92-93, št. 8, fragment. 90

B e $\mathbf{n}$ a m i n I pavec, glas, klavir, besedilo. [1896]. 5 str., $4^{0}$. - Pet Prešernovih pesmi 1949, str. 9-12.

91

Poročila in ocene: K[arel] Hoffmeister, LZ 16/1896, str. 454-455, docela izkomponirana pesem, $\mathrm{v}$ kateri rasteta oblika in melodijska fraza naravnost iz besede. - Anton Jeršinovič, LZ 34/1914, str. 104, B. Ipavec se je lotil pesmi šele leta 1896. - Vilko Ukmar, Zbornik slovenskih samospevov I/1953, str. 5, o prekomponirani obliki samospeva.

J o s i p M i c h 1, sopran, klavir, besedilo. - J. Michl: Štiri Prešernove pesmi 1921, str. 2-7, št. 1 .

Ocena: V[ladimir] L[ovec], LdP 11/1950 (9. 12.), št. 293, str. 3, o poglobljenem izrazu in razumevanju Prešernove misli.

S lavko O sterc: Mati. La mère. Poème symphonique. [Posvečena] Viktorju Andrejeviču Plotnikovu. Partitura. Ljubljana, 30. 11. 1940, (20) str., $4^{0}$.

Ms NUK, glasbena zbirka 131/48-192.

S lavko O sterc : Nezakonska mati. Baletna slika po zamisli koreografa Borisa Pilata. Klavirski izvleček. 24. 11. 1940, 12 str., $4^{0}$.

Ms NUK, glasbena zbirka 131/48-187. - Ni zložena direktno na Prešernovo besedilo, pač pa spremlja čustva, ki jih je položil Prešeren v svojo pesem. - Poročilo: Marijan Lipovšek, Slovenska glasbena revija, glasbenoknjiž. pril. 1/1951-52, str. 44. Andrej Li is a c, glas, klavir, besedilo. - A. Lisac: Mati. Šst samospevor s klavirjem 1940, str. 3-5. 
Rokopis v knjižnici Glasbene akademije II-1084.

)O Vrbac

št. 2.

B red a Š č e k, glas, klavir, besedilo. — B. Šček: Oj Vrba; 1954, str. 6-8,

)Oči sem večkrat vprašalı

A n t o n B a l a t k a, bas, besedilo. Ljubljana 1925, 3 str., $4^{0}$. Ms NUK, glasbena zbirka 1648/55.

Danilo Švara, sopran, klavir, besedilo. - D. Švara: Dva speva iz opere »Prešeren« za sopran in klavir. Ljubljana 1954, str. 3-8.

Od Rošlina in Verjankota

Matija Tome: Rošlin in Verjanko. Mešani zbor, besedilo. Ljubljana 21. 12. 1946, 5 str., $4^{0}$.

Rokopis je last skladatelja.

Od železne ceste

Dvospev. Skladatelj in note neznane.

Poročila: [Janez Bleiweis], Novice 4/1846 (18. 2.), list 7, str. 28, (25. 2.) list 8, str. 32, o igri »Poskušnja kranjskih pesem(, ki so jo predvajali 14. 2. 1846 v ljubljanskem gledališču. Predstavo je vodil Gašpar Mašek. Peli so tudi pesem »Od železne ceste๔ (Molt - Andrejčik, Majerhoferjeva-Barbika). Ponovitev predstave je bila 22. 2. 1846. - Novice 4/1846 (1. 4.), list 13, str. 52 oglas: „Viže unidan v ljubljanskem gledišu petih čveterih pesem se dobijo $v$ note postavljene za klavir 40 krc., za celo muziko pa za 4 gold. (Teh viž doslej še ni bilo mogoče odkriti.) Pavel Kozina, Zbori, glasbenoknjiž. pril. 7/1931, št. 2, str. 10, pripisuje napev Fleišmanu.

K a m i l o M a š ek, glas, klavir, besedilo. - Slovenska gerlica VI/1859, str. 14-17, št. 14 .

Ocena: Gojmir Krek, Novi akordi, glasbenoknjiž. pril. 12/1913, str. 33, napev skače $\mathrm{v}$ tempu di polka.

J u ri j Fleišm a n, dvospev, klavir, besedilo. - J. Fleišman: Mične slovenske zdravice [1860], zv. I, str. 9-11.

102

J u ri j L a pa $\mathbf{n} \mathbf{j}$ a, glas, klavir, besedilo. - J. Lapanja: Missa in A für Organo [b. 1.], str. 56.

NUK Ms, glasbena zbirka 1077/57. [1889].

Andrej (Hrabroslav) Volarič, zbori, samospevi, klavir, besedilo. grada. - Poročila: Fran Rákuša: Slovensko petje 1890, str. 168. „L. Podgornikova je imenovala to delo opereto in nuceণc. - David Doktorič, Pevec 10/1930, št. 2, str. 10.

M a t i j a T o m c, dvospev: sopran-tenor, alt-bas, klavir, besedilo. Ljubljana 1946, s str., $4^{0}$.

Rokopis hrani Luka Kramolc.

Orglar

Rados I a H rovatin, mešani zbor, sopran in tenor solo. Ljubljana 1942, 15 str., $4^{0}$.

Avtor posveča skladbo Pevskemu zboru Glasbene matice ob njeni sedemdesetletnici. - NUK Ms 1742/55.

Marija n Li povšek : Kantata. Partitura za zbor, solo in orkester. Ljubljana [1951.], 107 str. + 18 str. obveznega vložka, $4^{0}$. Rokopis je last avtorja. - 
Note za 30 glasbil. 1951, $4^{0}$. Rokopis v arhivu Slovenske filharmonije 394. - Mešani

zbor. Ljubljana. Opalografija 1951, 8 str., $4^{0}$.

107

Poročilo: Marijan Lipovšek, Radio Slovenija 1/1951, št. 2, str. 5-6, nastanek in analiza kantate.

Pesem moja je posoda tvojega imena

Gazela. Fra n c e Maro 1t, mešani zbor, besedilo. - NUK Ms Glasbena zbirka.

108

Pevcu

J o s i p M i ch 1, bas, klavir, besedilo. - J. Michl: Štiri Prešernove pesmi 1921, str. 14-16.

109

Ocene: Pavel Šivic, SPor 7/1946, št. 28, str. 3, skladba je pravi biser. V[ladimir] L[ovec], LdP $11 / 1950$ (9. 12.), št. 293, str. 3, odliki samospeva sta poglobljen izraz in razumevanje Prešernove misli.

K 1 a r o M i z erit, kantata. Note neznane.

Poročilo in ocena: Slovenska glasbena revija, glasbeno-knjiž. pril. 1/1951-52, str. 53, o izvedbi na koncertu Slovenske filharmonije $\mathrm{v}$ sezoni 1952-53. - Valens Vodušek, Naši razgledi 1/1953, št. 1, str. 21-23, glasba ne odgovarja vsebini Prešernove pesmi.

V i 1 k o U k m a r, mešani zbor, besedilo. [Ljubljana 1955.], 13 str., $4^{0}$. 111

Rokopis v arhivu Slovenske filharmonije 1193.

Pad oknom

M a ri ja pl. Ves t. Note neznane.

Poročilo: Fran Potočnik, DS 38/1925, str. 278. - Dragotin Cvetko: Zgodovina glasbene umetnosti na Slovenskem III/1960, str. 86-87. Kako je pesem vplivala na Prešerna, ko sta mu jo leta 1848 zapela Victor von Vest in Fran Potočnik v stražarnici narodne straže $v$ Kranju.

J u rij F l e išma n, glas, klavir, besedilo. - Slovenska gerlica I/1848 in $\mathrm{I} / 1852$, str. $12-13$.

113

Poročila in ocene: [Joseph] Babnigg, IB 1848 (23. 6.), Nr. 51, str. 204. [Janez Bleiweis], Novice 1848 (28. 6.), list 26, str. 110. - Anton Trstenjak: Slovensko gledališče 1892, str. 36, o uspelem predvajanju pesmi na drugi slovenski besedi, ki jo je priredilo Slovensko društvo 19. 6. 1848. - Leopold Kordesch, IB 1848 (14. 10.), Nr. 83, str. 332, o izidu I. zvezka Slovenske gerlice in pohvala Fleišmanovih napevov, ki so origlinalni, ljubki, $\mathrm{v}$ narodnem duhu in polni zanosa.[Anton Trstenjak], Slovan 1885, str. 108-109, poroča po Hribarjevi beležki, da pojejo v goriško-furlanskih cerkvah Tantum ergo po tem napevu. - V[ladimir) L[ovec], LdP 11/1950 (9. 12.), št. 293, str. 3, skladba je v bistvu zgrešila svoj umetniški namen, ker je opredelila samo okolje pesmi, ne pa njene vsebine. - Vlado Golob, Slovenska glasbena revija, glasbenoknjiž. pril. 2/1953-54, str. 5, odlika te pesmice je $\mathrm{v}$ tem, da glasba $\mathrm{v}$ ubranosti ustreza besedilu. - Fleišmanov rokopis: NUK Ms 492 IV, str. 26, mapa $31 \mathrm{f}^{0}$.

J u ri j F le išm a n, moški zbor, besedilo. - Gerlica, nova izdaja I/1864, str. 12-13. - Gregor Tribnik: Slovenske pesmi za čveteri moške glase, Dunaj 1864, str. 4. - Zbirka slovenskih napevov ubranih za čvetero ali petero moških glasov, Ljubljana 1877, zvezek IV, str. 14, št. 10. - Lavorika I[1880], prva in druga izdaja str. 21 (22), št. 14. - Lavorika III[1882], str. 13, št. 10. - V. vseh treh Lavorikah zborovska garnitura. - Barčica, tretja izdaja. Gorica. Goriška Mohorjeva družba 1944, str. 57.

Poročilo: Pavel Kozina, Zbori, glasbeno knjižni del 1931, str. 10.

Fleišmanov napev za štiri moške glasove harmoniziral J o s i p Č e ri n. J. Čerin : Štiri narodne pesmi. Op. 5., 1897, str. (8), NUK Ms, glasbena zbirka 1670/55. - 
Zbori. Pesmarica Glasbene matice, uredil J. Čerin 1897, 1. in 2. natis str. 133, 3. natis 1908 , str. 133 .

Fleišmanov napev za mešani zbor priredil Anton Foerster. Zbirka slovenskih narodnih pesnij. Ljubljana. Glasbena matica, zvezek X/1882, str. 14-15. Ludvik Kuba: Slovanstvo ve svych spěvech VII/1889, kn. I, str. 108-109. 116

Fleišmanov napev za mešani zbor priredil $\mathrm{M}$ a t e j $\mathrm{H} \mathrm{ubad}$. M. Hubad: Slovenske narodne pesmi, harmoniziral in za koncert priredil M. Hubad. Ljubljana. Glasbena matica [1894], str. 8, št. 7; 1942, str. 4-5. - Prešernov dan 1946, str. 38-39, hrvatska izdaja str. (47-48). - Sedem Prešernovih pesmi 1948, str. (5-6). - Naši zbori 1/1946, snop. 5, str. (8), opalografirano [1955], 1 str., 4. 117

Fleišmanov napev za mešani zbor priredil Emil Ada mi č. E. Adamič : 100 narodnih pesmi 1937, str. 53, št. 41 z opombo: ponarodela, varianta. $\quad 118$

Po B. Ipavčevem baritonskem napevu J. Nollijeva varianta. Zbor Fleišmanov. Matej Hubad: 33 mešanih in moških zborov. Ljubljana, Glasbena matica 1903, zv. XXXII, str. 54, št. 25.

Fleišmanov napev za samospev in klavir priredil Anton Foerster. Triglav, Slovenske pesmi za samospev s spremljevanjem klavirja I[1887], str. 8, št. 6 $\mathrm{s}$ pojasnili $\mathrm{v}$ češčini pod črto.

Ocena: A[nton] R[azinger], LZ 7/1887, str. 316-317. „Glasovi so stavljeni v srednji višini, da jih bode možno prepevati visokim in nizkim glasovom. Spremljanje na klavir je vzgledno, ni ravno navadno, a povsem preprosto in vendar $s$ finim okusom ubrano.»

Fleišmanov napev enoglasno, slovensko besedilo. - Vjekoslav Klaić: Hrvatska pjesmarica. Sbirka popjevaka za skupnu pjevanje. Zagreb, Matica hrvatska 1893, str. 188.

Fleišmanov napev za samospev s klavirjem, besedilo. Priredil I v a n Z o r m a n. I. Zorman: Slovenske melodije. Pesmi za solo, dvospev, ženski in mešani zbor. [Joliette, Illinois] 1950, str. 4.

Fleišmanov napev dvoglasno, besedilo. - I v a n Gr b e c : Pesmarica za osnovne, nižje srednje in strokovne šole. Trst I/1954, str. 100.

Transkripcija narodne pesmi »Luna sije« [Fleišmanov napev] za glasovir zložil in visokorodni gospici Mariji Winklerjevi udano poklonil Danilo Fajgelj. Ljubljana. Glasbena matica 1881, 10 str., $4^{0}$.

Brez besedila. - Poročilo: Fran Hlavka, LZ 2/1882, str. 58. Skladba »je lahko umevna, ima uvod, temo in štiri variacije te arije«. - Fran Rakuša: Slovensko petje 1890 , str. 143 .

Ständchen. Serenade. Übersetzt von Anton Funtek. Rud [olf] Wein w u rm : Alpenstimmen, Neue Serie 1904, str. 6, Nr. 5. (Universal Edition, Nr. 2451.)

Fleišmanov napev $\mathrm{s}$ podloženim nemškim prevodom pesmi iza piano solo.

Fleišmanov napev za klavir priredil Ka r e l J e r a j. K. Jeraj: 14 slovenskih narodnih pesmi. 14 slovenische Volkslieder, Wien [191.], str. 9, št. 8.

Naslov: Pod oknom - Ständchen. Podloženo slovensko besedilo in Funtkov nemški prevod.

Fleišmanov napev za klavir priredil A n to n J a k l. A. Jakl: Slovenski biseri. Veliki narodni potpuri. Op. 40 [1918], str. 7, št. 13. Brez besedila.

Fleišmanov napev za klavir priredil J osip. Pavši č. J. Pavšič: Klavirski album za slovensko mladino za nižjo in srednjo stopnjo klavirskega pouka. Ljubljana. Glasbena matica [1920], str. 3; 2.-4. izdaja [1934], str. 2. 
Luna sije. Serenadenlied. Für die Zither arrang. Josef Sorg. J. Sorg: Album für Zitherfreunde. Agram. [b. 1.], Heft 1, Nr. 1, str. 1.

Fleišmanov napev brez besedila.

Fleišmanov napev za citre priredil [Fran Korun] Fran Sal. Koželj. ski. F. S. Koželjski : Poduk v igranju na citrah $\mathrm{I} / 1895$, str. 19, št. 17.

Brez besedila.

Fleišmanov napev za citre priredil I va n Kiferle. I. Kiferle: Slovenske narodne pesmi za citre in petje VII/1917, št. 9, VII/1920 št. 9, VII/1936, št. 9.

131

Fleišmanov napev za violino in klavir z napevom priredil Fran Kor u n. Album slovenskih napevov, uredil Fran Gerbič. I[1899], str. 35-36, št. 49, enako 2. natis 1900 .

Fleišmanov napev za dve violini priredil Franjo Serajnik: Jugoslovanske narodne pesmi za dvoje gosli, I[1932], str. 12.

Za godalni kvintet in klavir priredil Lavoslav Pahor. - Lavoslav Pahor: Tri narodne slovenske.

Glej: Strojepisna biografija s seznamom skladb Lavoslava Pahorja, ki je bila leta $1947 \mathrm{v}$ arhivu Glasbene matice. - Napev je domnevno Fleišmanov.

Fleišmanov napev za tamburaški zbor prideril $H$ [rabros lav $O$ t mar $] \quad V$ o

g r i č. - Slavjanska lira I/1900, št. 6, str. 87-88, št. 3. 135

Fleišmanov napev za kitaro priredil $\mathrm{Stane} K \mathbf{r a n j}$ c. - Stane Kranjc: Venček slovenskih pesmi za kitaro [1944], št. 1. 136

Fleišmanov napev za harmoniko priredil Pavel Ran čigaj. - Pavel Rančigaj: Narodne pesmi za klavirsko, kromatično in diatonično harmoniko. Ljubljana [1946], zv. 5, str. 8.

K a mi l o M a š e k, b-dur, glas, klavir, besedilo. - Slovenska gerlica V/1859, str. 8-9. - Zbornik slovenskih samospevov. I/1953, str. 21.

Ocene: Gojmir Krek, Novi akordi, glasbeneknjiž. pril. 12/1913, str. 33, uglasbeno kot hrvatsko kolo. - Vilko Ukmar, Zbornik slovenskih samospevov I/1953, str. 5 , kitična pesem.

K a m i l o M a š e k, e-mol, glas, klavir, besedilo. - Slovenska gerlica V/1859, str. $10-11$.

Theodor Elze : Unter dem Fenster. Frei übersetzt von Luise Pesjak. Für eine Singstimme mit Begleitung des Pianofortes. Laibach 14. 3. 1865, 3 str. $20.5 \times 29 \mathrm{~cm}$.

Ms NUK Glasbena zbirka. 1878/49. - Komentar: Dragotin Crvetko: Zgodovína glasbene umetnosti na Slovenskem III/1960, str. 87-88.

A n ton H a jdrih, četverospev, besedilo. - Anton Hajdrih: Jadranski glasovi I/1876, str. 6. - Lavorika II[1881], 1. in 2. izdaja, str. 24, št. 14. - Ludvik Kuba: Slovanstvo ve svych spěvech VII/1889, kn. I, str. 108-109. - Zbori. Pesmarica Glasbene matice. Uredil Josip Čerin. 1. izdaja, 1. in 2. natis 1897, 3. natis 1908, str. 161. - Zbori. Pesmarica Glasbene matice. Uredil po Čerinovi izdaji Matej Hubad. 2. izdaja 1. natis 1922 , 2. natis 1929 , str. 256. - Pesmarica Glasbene matice 3. izdaja, I. zvezek 1944. - 24 moških zborov. Ljubljana. Državna založba Slovenije 1945, str. 81. - Mala pesmarica 1920, št. 4. - Anton Hajdrih: Pesmi 1936, str. 4-5, št. 4. - [Otmar Pelan] Pelot, Zbirka priljubljenih slovenskih pesmi 1941, zv. 1, str. 21-23, št. 6, opalografirano. Ljubljana 1955, 1 str., $4^{0}$.

Ocena: Robert Bežek, SN 16/1883, št. 11, str. 1-2. »Zaradi svojega mehkega značaja je skladatelj imel $v$ mislih le hrepenenje, ker si je preveč predstavljal le prvo kitico.đ 
Hajdrihov napev za klavir priredil Vikt or Parma. Viktor Parma: Slovenske cvetke. Potpouri po slovanskih napevih za glasovir. Ljubljana (1900), str. 6-7. Enako v ostalih izdajah. 142

Hajdrihov napev za tamburaški zbor zložil H[rabroslav $0 \mathrm{tmar}]$ Vo g r i č. - Slavjanska lira $I / 1900$, št. 6, str. 88, št. 4.

Hajdrihov napev za citre priredil Ka rol Wilfan. - K. Wilfan: Slovanski citrar, Ljubljana, [b.1.] str. $4 . \quad 144$

Hajdrinov napev za citre priredil Ivan Kiferle. - Ivan Kiferle: Slovenske narodne pesmi za citre in petje zv. VIII, 2. izdaja 1920, str. $4 \quad 145$

A n t on Nedvěd, moški zbor, tenor solo, besedilo. - Anton Nedvěd: Štirje slovenski napevi za moški zbor vglasbil in poklonil slovenskemu pevskemu zboru ljubljanske čitalnice. 1882, Zv. XII, str. 7-8, št. 3. - Lavorika III[1882], 1. in 2. izdaja, str. 23-25, št. 15, zborovska garnitura. - Zbori. Pesmarica Glasbene matice. Uredil Josip Čerin. Prva izdaja 1 . in 2. natis 1897, 3. natis 1908, str. 187-189. Zbori. Pesmarica Glasbene matice. Uredil po Čerinovi izdaji Matej Hubad. 2. izdaja, 1. natis 1922, 2. natis 1929, str. 276-278.

Poročila in ocene: Programm der Sommer-Liedertafel veranstaltet vom Männerchore der philharmonischen Gesellschaft in Laibach am 12. Juli 1880. Ta pesem je bila novost in jo je pel tenorist Anton Razinger. - Robert Bežek, SN 16/1883 (15. 1.), št. 11, str. 2. „Skladatelj je preveč poudarjal Prešernov obup, kar pa ni glavna misel pesmi.«

Vilhar Fra n., mešani zbor, besedilo. - Fran S. Vilhar: Skladbe I[1883], str. 51. Enako v hrvatski izdaji.

Ocene: Vojteh Valenta, Kres 4/1894, str. 270-271, o popularnosti napevov v zbirki Skladbe I. - Danilo Fajgelj, LZ 4/1884, str. 183, lep, veličasten zbor, ki utegne izpodriniti Fleišmanovega, ki je nemškega izvora. - Robert Bežek, SN 16/1883 (15. 1.), št. 11, (16. 11.), št. 263, str. 2-3, kratka razčlemba kompozicije. Vilharjev napev za tamburaški zbor zložil $H$ [rabroslav 0 tmar] Vo g r i č. - Slavjanska lira $I / 1900$, št. 6, str. 86-87. . 148

Gustav Adolf $\mathrm{Schmidt,} \mathrm{samospev,} \mathrm{klavir,} \mathrm{podložen} \mathrm{Samhaberjev} \mathrm{nem-}$ ški prevod. - An der schönen blauen Donau, Wien 1892 (15. 11.), Nr. 22, glasbena priloga.

Poročilo: LZ 13/1893, str. 255. - Fran Vidic, LZ 20/1900, str. 839.

G o j m i r K r k, samospev za bariton, klavir, besedilo. Ljubljana. L. Schwentner [1900], 9 str., $4^{0}$.

Ocene: E[vgen] Lampe, DS 14/1901, str. 62, o harmoničnih efektih skladbe, ki bi po svojem besedilu morala biti milo-lirična. - Fran Gerbič, LZ 20/1900, str. 868, skladbo je zložil za pesnikov jubilej. - Vladimir Foerster, LZ 21/1901, str. 67, dobro premišljena skladba, ki vestno odgovarja pesnikovim intuiciam. Novice $58 / 1900$ (14. 12.), št. 50 , str. 490 , poročilo o izidu pesmi. - Slovenec $28 / 1900$ (6. 12.), št. 280 , str. 2 , težavna skladba, ki zahteva od pevca obilo vaje in točnosti. - Slovenka $5 / 1901$, str. 19, skladatelj je dal vsaki kitici poseben napev tesno držeč se pesnikovega besedila.

Mirko Poli č, moški zbor, besedilo. - NUK Ms Glasbena zbirka. 151

B reda Ščk, glas, klavir, besedilo. - Breda Ščk: Oj Vrba, 1954, str. $2-5$, št. 1 .

Da nil o Švara. Glej: Slovo od mladosti. Opera »Prešerenc.

Povodni mož

Viktor Parma : Balada za soli, zbor in orkester. Uglasbil in slavnemu pevskemu zboru Glasbene matice poklonil Viktor Parma. Priredba za klavir in petje, 
Ljubljana [1911], 30 str. $4^{0}$. - Basovski part, Ljubljana, Glasbena matica [1911], 10 str., $4^{0}$. - Note za sopran 9 str., alt 9 str., tenor 10 str., bas 10 str., $4^{0} . \quad 153$

Ms Arhiv Slovenske filharmonije 220. - Poročila in ocene: O koncertu Glasbene matice 10. 5. 1911, kjer so pod vodstvom Matije Hubada predvajali balado s karakteristiko skladbe (melodioznost, ritmičnost, narodni motivi). - Stanko Premrl, DS 24/1911, str. 242-243. - Jutro 2/1911 (12. 5.), št. 432, str. 2. - LZtg 1911 (10. 5.), Nr. 107, str. 997, (11. 5.), Nr. 108, str. 1010-1011. - Emil Adamič, LZ 31/1911, str. 334. - Anton Jeršinovič, LZ 31/1911, str. 334-335. - [Anton Lajovic] Novi akordi, glasbenoknjiž. pril. $9 / 1909-1911$, št. $4-5$, str. 38, 10/1910-11, št. 4-5, str. 52-53, 61. - [Pavel Kozina] K., Slovan 9/1911, str. 189. - A[nton] S[vetek], Slovenec 39/1911 (11. 5.), št. 108, str. 1. - M. N., SN 44/1911 (11. 5.), št. 109, str. 3-4. - SN 45/1912 (15. 1.), št. 11, str. 5, o koncertu Glasbene matice v. Ljubljani 14. 1. 1912 in o skladbi. - Tabor 2/1921 (2. 4.), št. 74, str. 2, (8. 4.), št. 78, str. 3, o koncertu gojenk in gojencev mariborskega učiteljišča 5. 4. 1921 in o narodni toplini balade. - H[erbert] Svetel, Radio Ljubljana 1939, št. 7, str. 1-3, o skladatelju in skladbi.

S lavko Osterc: Simfonična slika po Prešernovi baladi. Partitura 1924, 51 str., $4^{0}$.

Besedilo ni podloženo. Ms NUK Glasbena zbirka 131/48-227. - Poročilo: Marijan Lipovšek, Slovenska glasbena revija, glasbenoknjiž. pril. 1/1951-52, str. 44.

Anton Pogačar: Plesne melodije iz operete »Povodni možc po istoimenski Prešernovi baladi. Besedilo Zdenka Leskovec-Pogačarjeva. Priredba za klavir, Ljubljana 1946, 9 str., $4^{0}$.

155

A n ton Pog a č a r : Venček melodij iz operete »Povodni možđ po istoimenski Prešernovi baladi. Besedilo Zdenka Leskovec-Pogačarjeva. Priredba za klavir, Ljubljana 1946, 13 str., $4^{0}$.

B laž A rni č : Baletna simfonična slika. Op. 38, partitura za godala, pihala, trobila in tolkala. 24. 5. 1950, 110 str., $4^{0}$.

157

Note za 29 glasbil posamič. Ms Arhiv Slovenske filharmonije 764. - Poročila in ocene: R[afael] Ajlec, Ljubljanski dnevnik 8/1959 (8. 6.), št. 132, str. 2. Ples Povodnega moža je bil izveden na simfoničnem koncertu Slovenske filharmonije 8. 6. 1959, dirigent Zvonimir Ciglič, harfistka Pavla Uršič-Petričeva. Izvedba je pokazala, da je v luči nekakega surrealizma to delo močna skladba. - Blaž Arnič, Radio Slovenija 1951, št. 2, str. 6-7. Skladbe »nisem pisal direktno po Prešernovem tekstu, vendar me je Prešeren tudi inspiriralı. - Pavle Kalan, Slovenska glasbena revija glasbenoknjiž. pril. 1/1951-52, str. 22. Skladatelj se je naslonil v prvi vrsti na ritem, ki veje že iz Prešernove pesmi.

Danilo Švara. Glej: Slovo od mladosti. Opera »Prešerenđ.

Prešernova vera

L u cijan Marija Škerjan c : Epigram. Moški zbor, besedilo. Ljubljana 1944, 2 str., $4^{0}$.

Ms NUK Glasbena zbirka 2846/54.

Prophetischer Trost für den Traun im Jahre 1825. Glej: Zarjovena dvičica.

Prošnja

K a mi l o M a š e k, glas, klavir, besedilo. - Slovenska gerlica V/1859, str. $12-13$, št. 4 .

J u r i j F le i šm a n, Samospev, klavir, besedilo. - [Dvainštirideset pesmi, b. 1.] str. 57 in 58 , št. 38 .

NUK, Ms, glasbena zbirka 2549/55.

E d v a r d V a l e n t a, samospev, klavir. Note neznane.

Poročila: Vojteh Valenta, SN 9/1876 (3. 12.), št. 278, str. 3. - Fran Gerbič, LZ 20/1900, str. 867, o obstoju skladbe, ki ni bila tiskana. 
Fra n c e Ma r o lt, mešani zbor, besedilo. - NUK Ms, Glasbena zbirka. 162 Ribič

[Friderik Širca] = Rist o Savin : Barcarola. Klavir. Op. 6, št. 2. - Novi akordi 2/1902-1903, št. 3, str. 37-38.

Brez besedila, a v smislu Prešernove pesmi.

B r e d a Š č e k, glas, klavir, besedilo. - B. Šček: Oj Vrba; Ljubljana 1954, str. 9-13, št. 3 .

Rošlin in Verjanko. Glej: Od Rošlina do Verjankota.

Rotarjevima dekletoma

J a ko b Š e gu l a, mešani zbor, besedilo. - J. Šegula: Tri pesmi za mešani zbor, Ljubljana, opalografija 1954, 2 str., $4^{0}$. - Ponatis 1955, 1 str., $4^{0}$.

165

Serenada. Glej: Pod oknom. Rudolf Weinwurm.

Serenadenlied. Glej: Pod oknom. Joseph Sorg.

Sila spomina

K a m i l o M a š ek, glas, klavir, besedilo. - Slovenska gerlica V/1859, str. $22-23$, št. 8.

J u ri j F l e i šm a n, moški zbor, klavir, besedilo. - J. Fleišman: Slovanska beseda. Pesmi za veselice [1864], zv. 2, str. 5-6.

गSlep je, kdor se s petjem vkvarja↔. Glej: Glosa. Emil Adamič.

Slovo od mladosti

Danilo Švara: „Okusil zgodaj sem tvoj sad, spoznanjecc. Glas, klavir, besedilo. D. Švara: Trije spevi iz opere »Prešeren 1954, str. 3-5.

\section{Soldaška}

K a mi l o M a š e k, za tri moške glase, G-dur, 2/4 takt, besedilo. - Slovenska gerlica VI/1859, str. $6-7$, št. 10 a.

K a m i lo M a š e k, za četere moške glase, g-mol, 4/4 takt, besedilo. - Slovenska gerlica VI/1859, str. 8-9, št. 10 b. - Prešernov dan 1946, str. 40-41, hrvaška izdaja str. (49-50). - Sedem Prešernovih pesmi 1948, str. (7-8). 170

K a mil o M a š e k, Vojaška. Moški zbor, G-Dur, 2/4 takt, besedilo. — Lipica. Slovenski napevi za moške glasove [b. 1.] str. 24-26, št. 13. Hrani knjižnica Glasbene akademije II-2196. - Lavorika I [1880] 1. in 2. izdaja št. 34, zborovska garnitura.

Poročilo: Pavel Šivic, Naši zbori, glasbenoknjiž. pril. 4/1949, str. 1. kitična skladba »predstavlja zaradi svojske in okusne obdelave obogatitev naše zborovske literature

Vojaška. Maškov napet za citre priredil [Fran Korun] Fran Koželj ski. - F. Koželjski: Pouk v igranju na citrah II/1896, str. 33, št. 32.

Maškov napev za tamburaški zbor priredil H[rabroslav Otmar] Vog r i č. - Slavjanska lira $\mathrm{I} / 1900$, str. 93-94, št. 9.

Andrej Vavken, moški zbor, besedilo. - Andrej Vavken: Napevi za petje [b. 1.], str. 12.

Ms NUK Glasbena zbirka 2809/54.

[ A non i mna skladba.] Moški zbor, besedilo.

Leta 1948 je bila skladba še $v$ arhivu Glasbene matice, danes je rokopis neznano $\mathbf{k j e}$. 
B e $\mathbf{n}$ a m i n I p a vec, moški zbor: 1. in 2. tenor, 1. in 2. bas, besedilo. Ljubljana. Ljubljanska čitalnica [1867], str. (3). Zborovska garnitura.

176

[ S a š a Š a t e l :] Vojaška. Moški zbor, besedilo. - [Dvainštirideset pesmi, b. 1.] str. $1-3$, št. 2 .

Ms NUK Glasbena zbirka 2549/55. - Skladba je domnevno Santlova.

Anton B a la t ka, moški zbor. Note neznane.

Podatek je vzet iz skladateljevega pisma iz Brna 4. 3. 1931, ki je bilo leta 1947 $\mathrm{v}$ arhivu Glasbene matice.

[ P a vel Šivic] Lju ulja nski, dvoglasno, besedilo. - Prešeren glasnik naše borbe in naše svobode, februar 1945, priloga.

179

[ P avel Śivic] L jublja nski, moški zbor, besedilo. - Prešernov dan 1946, str. 39-40, hrvaška izdaja 1946, str. (48-50). — Sedem Prešernovih pesmi 1948, str. (6-7). - Naši zbori 4/1949, sn. 1, str. 13-14. NUK Ms, Glasbena zbirka.

180

Poročilo: [Adolf Groebming] Gg, Naši zbori 4/1949, sn. 1 (III. ov. stran). Uglasbena za Prešernovo proslavo v Crnomlju febr. 1945, o izreki pri izvajanju.

Pavel Šivic, mladinski zbor, besedilo. Ljubljana, opalografirano 1954, 1 str., $4^{0}$.

V i n k o V od o p i ve c, mladinski mešani zbor, besedilo. - Naši zbori 4//1949, sn. 1, str. 15-16. - NUK Ms, Glasbena zbirka.

182

Poročilo: [Adolf Groebming] Gg, Naši zbori 4/1949, sn. I (III. ov. stran). Skladba se odlikuje po majhnem glasovnem obsegu. $O$ izreki pri izvajanju.

S lavko Mihel ľ i č, mešani zbor, besedilo. Ljubljana, opalografija [195.], 2 str., $4^{0}$

Slavko Mihelčič, četveroglasni mladinski zbor, besedilo. Ljubljana, opalografija [1952], 2 str., $4^{0}$.

Sonet. Glej: „Mars'kteri romar«. Lucijan Marija Škerjanc.

Soneti

G a š p a r M a š e k, moški zbor, klavir, 1874 .

Note neznane. - Poročila: Vojteh Valenta, SN 9/1876 (3. 12.), št. 278, str. 3. - Fran Gerbič, LZ 20/1900, str. 876. Ker skladatelj ni bil vešč slovenskega jezika, nimajo te skladbe nobene glasbene vrednosti.

Soneti nesreče

Bogo Leskovic, visoki glas (tenor) in orkester. Partitura, Ljubljana 23. 1. 1951, 83 str., $4^{0}$. Rokopis je last skladatelja. - Note za 26 glasbil. Ljubljana 1950, $4^{0}$. Ms Arhiv Slovenske filharmonije 395.

186

Vsebina: 0 Vrba, Popotnik, Hrast, Komur, Življenje ječa, Čez tebe. Besedilo ni podloženo. - Poročilo: Bogo Leskovic, Radio Slovenija 1951, št. 2, str. 7, o muzikalni rešitvi sonetne oblike.

Sonetni venec

Lucijan Marija Škerjanc: Sonetni venec dr. Franceta Prešerna za tenorski in basovski solo, tri soliste iz zbora (tenor, bariton, bas), moški zbor in veliki orkester. Partitura, Ljubljana 1938, 206 str. + vložek 6 str. + nova verzija od št. 116 dalje. 1939. Str. 202-231, $4^{0}$. - Klavirski izvleček. Moški zbor a cappela, klavir. Ljubljana 17. 2. 1938. $122+$ (I) str., $4^{0}$. + Besedilo Sonetnega venca »Pev'c nove ti cvetlice $v$ ven'c povije↔. 9 tipkanih listov. Rokopis je last Ludvika Zepiča.

187

Koncertni program Glasbene matice 26. februarja 1940, dirigent Mirko Polič. Pojasnila o kompoziciji, ki je bila dovršena 16. aprila 1938 z besedilom Sonetnega 
venca, kakršen je izšel kot priloga IB 1834. - Poročila in ocene: [Josip Birsa] Dr. B., Jutro 20/1940 (24. 2.), št. 45, str. 3-4, (29. 2.), št. 49, str. 3-4. Glasbena analiza kantate pred njeno krstno izvedbo in poročilo o koncertu Glasbene matice 26. 2. 1940. - M[aša] Slavec, Radio Ljubljana 12/1940, št. 9, str. 4. Razgovor s skladateljem o nastanku in izvedbi kompozicije. - [Valens Vodušek] VaVo, Slovenec 68/1940 (1. 3.), št. 50, str. 8. Skladba še ni popolnoma uravnovešena. - [Dragotin Cvetko] -cd, SN 73/1940 (22. 2.), št. 48, str. 4. 0 pomanjkljivostih kantate, ki so se pokazale ob njeni krstni izvedbi. - Anton Lajovic, Jutro $20 / 1940$ (7. 3.), št. 55, str. 7. O problemih, ki se pojavljajo ob Sonetnem vencu $\mathrm{v}$ glasbi.

Lucijan Marija Šerjanc: Sonetni venec dr. Franceta Prešerna. Kantata $v$ treh delih za soliste, zbor in orkester. Ljubljana. Slovenska akademija znanosti in umetnosti. (Notografiral Maks Simončič. Tiskal Grafični zavod Hrvatske, Zagreb.) $4^{0}$. (Dela SAZU. Razred za umetnosti 18. Serija za glasbeno umetnost 18.) I. del : 1959, $166+$ (II) str. - II. del : 1960, 140 + (II) str. - III. del : 1960, 100 str. Nova verzija iz leta 1948 na Prešernovo besedilo iz Poezij 1847 »Poet tvoj nov Slovencam venec vije $($ Matrice orkestralne partiture so na SAZU. - Zbor, ciklostil, Ljubljana 5. 1. 1949, 14 str. $4^{0}$. Ms Arhiv Slovenske filharmonije $302 . \quad 188$

Koncertni program Slovenske filharmonije ob 100-letnici Prešernove smrti 8. in 10. februarja 1949. - Poročila in ocene: C[iril] C[vetko], LdP 10/1949 (24. 2.), št. 47, skladba spada med najpomembnejšse tvorbe tovrstne slovenske glasbene literature. - V[ladimir] $\mathrm{L}$ [ovec], LdP 11/1950 (9. 12.), št. 293, str. 3, (10. 12.), št. 294, str. 4, o edinstvenosti široko zasnovane celovečerne kantate. - L[udvik] Z[orzut], Ljudski tednik 4/1949 (11. 3.), št. 156, str. 13, priznanje veliki kompoziciji. - [Adolf Groebming] Gg, Naši zbori, glasbenoknjiž. pril. 4/1949, št. 2, str. 10 in SPor 10/1949 (27. 2.), št. 49, str. 4, o koncertu Slovenske filharmonije 8. 2. 1949, ki ga je dirigiral Samo Hubad. - Danilo Pokorn, Slovenska glasbena revija, glasbenoknjiž. pril. 1/1951-52, str. 19, o obeh muzikalnih verzijah Sonetnega venca, prva iz leta 1938, druga iz leta 1948. - [Maks Unger] M. P. U., Vestnik Maribor 7/1951 (17. 1.), št. 14, str. 2, o koncertni izvedbi Slovenske filharmonije iz Ljubljane 20. 12. $1950 \mathrm{v}$ Mariboru.

Spomin Valentina Vodnika. Glej: V spomin Valentina Vodnika.

Ständchen. Glej: Pod oknom. Rudolf Weinwurm.

\section{Strunam}

K a m i l o M a š e k- Gregor R i a r, moški zbor, klavir, besedilo. Brez podpisa. - Slovenska gerlica III/1850, str. 14-15, št. 7. — K a mil o M a š e k, Slovenska gerlica V/1859, str. 2-5, št. 1. - G re g o r R i h a , Gerlica, nova izdaja III/1864, str. 15-17. - Opalografija, 2 str., $4^{0}$. Arhiv Slovenske filharmonije 679. - K a milo M a š ek, Lavorika I [1880], 1. in 2. izdaja, št. 40, zborovska garnitura. - Zbirka slovenskih napevov ubranih za čvetero ali petero moških glasov, Glasbena matica 1880, zv. VIII, str. 54-56. - Zbori. Pesmarica Glasbene matice. Uredil Josip Čerin. 1. in 2. izdaja 1897, str, 178-179, enako 3. izdaja 1908. Zbori. Pesmarica Glasbene matice. Uredil po Čerinovi izdaji Matej Hubad 1922, str. 269-270, enako 2. natis 1929. - Pesmarica Glasbene matice 3. izdaja 1944, zv. I, str. 134-135. - 27 moških zborov. Ljubljana, Državna založba Slovenije [1948], str. 134-135.

189

Poročila: [Vincenc Fereri] Klun, IB 1849 (24. 7.), Nr. 59, str. 233, pesem Kamila Maška so peli na besedi na Rožniku 18. 7. 1849. - Fran Rákuša: Slovensko petje 1890, str. 95, napev pripisuje Kamilu Mašku. - Anton Trstenjak: Slovensko gledališče 1892, str. 113, o predvajanju pesmi v deželnem gledališču v Ljubljani 23. 10. 1870. - Fran Gerbič, LZ 20/1900, str. 865, 868. Gerbiě trdi, da je napev v Gerlici III/1864 pomotoma pripisan Riharju, ker je v resnici Maškov. Pavel Kozina, Zbori, glasbenoknjiž. pril. 2/1926, str. 46-48; Življenje in svet 
10/1931, str. 714, 716; melodija razodeva, da je napev Riharjev. „Muzikalno najvišje vrednosti v III. zvezku Gerlice je brez dvoma Riharjeva Strunam, pri kateri je v prvi izdaji avtor zamolčan.« - Dragotin Cvetko: Zgodovina glasbene umetnosti na Slovenskem III/1960, str. 37-39, o glasbenem avtorstvu.

Napev Mašek-Rihar za mešani zbor in tenor solo priredil I g n a c $H_{1} \mathbf{a d} \mathbf{n} \mathbf{i k}$.

- Glasbena zora 2/1900, glasbena priloga zv. 12, str. 89-90.

190

Napev Mašek-Rihar za tamburaški zbor priredil $H[$ a broslav 0 tmar $]$

Vogri č. - Slavjanska lira 1/1900, št. 6, str. 88-90, št. 5 .

191

Napev Mašek-Rihar je uporabljen za prvo temo $v$ koračnici L e vos lava Pahorja. - Levoslav Pahor: Dve Prešernovi pesmi za simfonični orkester 1923, 2 str., $4^{0}$.

192

Ms knjižnica Akademije za glasbo Ia-80. Brez besedila.

Napev Mašek-Rihar za zbor in salonski orkester priredil S a š S a n tel. 1927.

Note neznane. - Glej: Pregled kompozitorskega dela Saša Šantla, Ms v arhivu Glasbene matice.

Napev Mašek-Rihar za citre priredil Ivan Kiferle. - Ivan Kiferle: Slovenske narodne pesmi za citre in petje 1936, zv. VII, str. 12-13.

Napev Mašek-Rihar za tenor in klavir, besedilo. - Pet Prešernovih pesmi 1949, str. $5-6$.

Davorin Jenko, samospev, klavir, besedilo. - Davorin Jenko: Slovenske pesmi za četverospev, samospev in klavir. Op. 1 [1861], str. 1-2. - Davorin Jenko: Samospevi z glasovirom [1880], str. (7-8), št. 4. - Davorin Jenko: 18 slovenskih pesnij za moški in mešani zbor, za eden glas, dva glasa in glasovir [1908], str. 3-4. — Žicam. „Zujte žice miloglasne«, preveo Ivan Trnski. Biserje jugoslavenskih pjesama, Zagreb, Edition Kugli, konzervatorijska izdaja br. 102. - Zbornik slovenskih samospevov II/1953, str. 5-7.

196

Poročila: O koncertu Glasbene matice v Ljubljani 6. 11. $1910 \mathrm{v}$ proslavo 50letnice budnice »Naprej«, kjer je tenorist Ljubiša Iličić pel Jenkov samospev »Strunam«: Stanko Premrl DS 23/1910, str. 556. - Jutro 1/1910 (7. 11.), št. 249, str. 2. - [Bajuk Marko] B., Slovenec 38/1910 (7. 11.), št. 253, str. 2. - Emil Adamič, Naši zbori, glasbenoknjiž. pril. 10/1911, str. 37, o isti proslavi 1. 4. 1911 v Trstu, kjer je pel samospev »Strunam《 tenorist Štefan Šink.

Da vor in J e n ko, četverospev, klavir, besedilo. - Davorin Jenko: Slovenske pesmi za četverospev, samospev in glasovir. Op. 1 [1861], str. 6. - Davorin Jenko: Fr. Prešernove pesmi za petje in glasovir. Op. 3, Vienne 1862, str. 8-9, št. 4. )Zujte strune(c. Beograd. Edition populaire, J. Frajt [b. 1.] br. 112. Podatki so po Karlu Mahkoti: Davorin Jenko 1935, str. 12.

197

Poročila: Slovenski glasnik 8/1862, str. 36, o dunajski besedi 16. 1. 1862, kjer je skladba žela veliko priznanje. - Vojteh Valenta, SN 9/1876 (3. 12.), št. 278, str. 1-3, skladba spominja na Maškovo, kar skoraj ne more biti drugače, ker so v obeh kompozicijah razliti Prešernovi čuti popolnoma primerno. - Dragotin Cvetko: Davorin Jenko 1955, str. 57-60, o svežem, pristno doživetem čustvu, polnim prisrčnega zanosa in navdušenja ob pesnikovem besedilu.

D a v o r i n J e n k o, moški zbor, besedilo. - »Žicam(. Bisernica, Zagreb 1874, str. 37, br. 112, zborovska garnitura, prevod Ivana Trnskega. - „Žicam«. Kolo. Sbirka izabranih hrvatsko-slovenskih mužkih sborova. Uredio Nikola Faller, Zagreb 1894, str. 211-212. Prevod Ivana Trnskega, skladatelj je Drag. Jenko! - Zbori. Pesmarica Glasbene matice. Uredil Josip Čerin 1897, 1. in 2. natis ter 3. natis 1908, str. 173-174. - Davorin Jenko: 18 slovenskih pesnij za moški in mešani zbor, za eden glas, dva glasa in glasovir 1908, str. 32. - Zbori, Pesmarica Glasbene 
matice. Po Čerinovi izdaji priredil Matej Hubad 1922, 2. natis 1929, str. 264-265. - Pesmarica Glasbene matice 3. izdaja zv. I/1944, str. 112-113. - H[inko] Druzovič: Lira II/1912, str. 150-153. - Žicam. Partiture nacionalnih, patriotskih i verskih pesama. Muški horovi. Prikupio Božidar D. Lukić. Beograd 1928, Knj. I, str. 348, br. 169. Prevod Ivana Trnskega, cir., navedba po Karlu Mahkoti: Davorin Jenko 1935, str. 12. - Prešernov dan 1946, str. 37-38, hrvatska izdaja 1946, str. (46-47). - Sedem Prešernovih pesmi 1948, str. (4-5). - Naši zbori 2/1947, str. 10. - 24 moških zborov, Ljubljana, Državna založba Slovenije [1948], str. 112-113. - Opalografija, Ljubljana 1955, 1 str., $4^{\circ}$.

198

Da vorin J enko, enoglasno. Podložen hrvatski prevod Ivana Trnskega. Žicam. Vjekoslav Klaić: Hrvatska pjesmarica. Sbirka popjevaka za skupnu pjevanje. Zagreb. Matica hrvatska 1893, str. 115-116. - Vlad. Đorđević: Narodna pevanka, Beograd 1926, str. 66-67. (Cir.)

199

Jenkov napev za klavir priredil Viktor Parma-Viktor Parma: Slovenske cvetke. Potpouri po slovenskih napevih za glasovir [1900], str. 4-5. - A[nton] Stöhr: Album hrvatskih pjesama, Zagreb, L. Hartman (Stj. Kugli) [b. 1.] zv. III, str. 57-58. $\quad 200$

Anton $\mathrm{Haj}$ drih, bariton solo z breněečim zborom. Note neznane. 201

Poročilo: Fran Rákuša: Slovensko petje 1890, str. 70. - Emil Adamič, Novi akordi 11/1912, glasbenoknjiž. pril. str. 39. Oba poročata o rokopisu 》Strunam in solzicam«, ki se nahaja v Hajdrihovi glasbeni zapuščini. Valentin Kosovel jo je izročil 1. 1911 tržaški podružnici Glasbene matice, ki je uradovala v Narodnem domu in je ob požaru 1. 1920 propadla.

M i r k o P o li č, moški zbor, besedilo. - Naši zbori 4/1949, zv. 1, str. 11-12.

- NUK Ms, Glasbena zbirka.

202

Ocena: [Adolf Groebming] Gg, Naši zbori 4/1949, št. 1 (III. ov. str.), skladba je lahko pevna, o izreki pri izvajanju.

B red a క̌ č k, glas, klavir, besedilo. - Breda Šček: Med rožami. Štiri pesmi za glas in klavir 1955, str. 14-15.

203

Podloženo je slovensko besedilo in nemški prevod Vide Rudolf.

》Strune, milo se glasite.c Glej: Strunam.

Sveti Senan

Vikt or P a rma, sopran, bariton, moški zbor, klavir, besedilo, 1922. Opalografija 1930.

Rokopis last Parmove družine. Oboje not ni bilo dosegljivih.

Tri želje

S a š a Š a n te 1, bas, klavir, besedilo. Pazin 29. 12. 1908, 3 str., $4^{0}$.

NUK, glasbena zbirka Ms $443 / 55$.

Trinklied. Glej: Zdravljica. Benjamin Ipavec.

Ukazi

K a m i l o M a š e k, glas, klavir, besedilo. — Slovenska gerlica V/1859, str. $17-19$, št. 6.

Ocena: Vilko Ukmar, Zbornik slovenskih samospevov I/1953, str. 5, o kitičnosti kompozicije.

Anton Hajdrih, samospev za tenor, klavir. Rokopis 23. 11. 1878, 2 str., $4^{0}$.

207

NUK, glasbena zbirka Ms 974/60. - Poročila: Fran Rákuša: Slovensko petje 1890, str. 70. - Emil Adamič, Novi akordi, glasbenoknjiž. pril. 11/1912, str. 39. Oba govorita o usodi rokopisa. 
Fra n c G e r b i č, četverospev, besedilo. Op. 15. - F. Gerbič : Slovenska jeka [1880], str. 8-9.

208

Fran H lavka, za štiri moške glasove, besedilo. - Zbirka slovenskih napevov. Glasbena matica IX/1881, str. 65-66. - Lavorika II [1881], 1. in 2. izdaja, str. 1-2, št. 1, zborovska garnitura.

209

Fran Ozbi č, moški zbor, besedilo. 2 str. V, 80. NUK, glasbena zbirka Ms 2786/54.

Fran Vilh ar, tenor, klavir, besedilo. - F. S. Vilhar: Skladbe I [1883], str. 14-15, enako $\mathbf{v}$ hrvatski izdaji. - Djulabije I. zv., str. 14-15, br. 3. Djulabije br. 70, konzervatorijska izdaja I. zv., str. 12-13, br. 3. - Zbornik slovenskih samospevov II/1953, str. 37-39.

Poročila in ocene: Vojteh Valenta, Kres 4/1884, str. 270, karakteristika skladbe. - Danilo Fajgelj, LZ 4/1884, str, 183, v čustvu, deklamaciji in spremljavi zgled samospeva. - Robert Bežek, Slovan 16/1883 (16.11.) št. 263, str. 1, premišljujoča skladba, ki ne more navdušiti. - Lucila Podgornik, Slovan 2/1885, str. 250-251, skladba je tematsko delo in ne napev žive domišljije. - [Vilko Ukmar], Zbornik slovenskih samospevov 2/1953, str. 37-39, skladba je izliv skladateljeve mehkočutnosti.

Vilharjev napev za tamburaški zbor priredil $H[\mathrm{rab}$ os lav $\mathrm{Otmar}] \mathrm{Vo-}$ g r i č. - Slavjanska lira I/1900, št. 6, str. 90-91.

Unter dem Fenster. Glej: Pod oknom. Theodor Elze.

$V$ spomin Andreja Smoleta

K a m i l o M a š e k, glas, klavir, besedilo. - Slovenska gerlica VI/1859, str. $12-13$, št. 13 .

J. Nik or o w i cz, moški zbor s soli. Garnitura: 1. in 2. tenor, 1: in 2. bas, skupaj 21 str., 4${ }^{\circ}$. Prepis Marka Bajuka.

214

Prirejeno na napev poljske himne »Z dymem požaru(. Podloženo je slovensko besedilo. Slovenski prireditelj neznan. - NUK, glasbena zbirka Ms 2298/49.

$V$ spomin Valentina Vodnika

J u rij F l e išman, mešani zbor, besedilo. - Slovenska gerlica III/1850, str. 16-17. - Gerlica, nova izdaja III/1864, str. 18-19.

Poročilo o izvajanju na prvi besedi ljubljanskega zbora $v$ ljubljanskem gledališču 30. 5. 1848: [Janez Bleiweis] Dr. B., Novice 6/1848 (7. 6.), list 23, str. 95-96 in Anton Trstenjak: Slovensko gledališče 1892, str. 35. - IB 1849 (13. 1.) Nr. 2, str. 16, o izvajanju na slavnostnem koncertu Slovenskega društva 1. 1. 1849 ob vselitvi društva $v$ staro Virantovo hišo.

K a mi lo M a š e k, glas, klavir, besedilo. - Slovenska gerlica VI/1859, str. $10-11$, št. 12 .

Maškov napev za štiri moške glasove priredil Greg or Tribnik. - Gregor Tribnik: Slovenske pesmi za čvetiri moške glase, Dunaj 1864, str. 10-11. : 217

A nt on $\mathrm{H}$ a j d rih, četverospev, besedilo. - Anton Hajdrih: Jadranski glasovi 1879, zv. II, str. 4. Knjižnica Glasbena matica II-641. - Anton Hajdrih: Pesmi. Izdal Viktor Steska 1936, str. 29-30, št. 15. - Kolo. Sbirka izabranih hrvatsko-slovenskih mužkih sborova. Uredio Nikola Faller, Zagreb 1894, str. 186-187, št. 59.

Vojaška. Glej: Soldaška. Kamilo Mašek.

$V$ so srečo ti želim

B r e d a Š č e k, glas, klavir, besedilo. - Breda Šček: Oj Vrba, 1954, str. $14-17$, št. 4 . 
Anonimno, glas, klavir, besedilo. Spremljavo improviziral L u d vik Z e pi č. Ljubljana 1959, 4 str., $4^{0}$.

Ms je Last Ludvika Zepiča.

Danilo Švara, Glej: Slovo od mladosti. Opera »Prešeren“.

Za slovo. Glej: K slovesu. Hrabroslav Volarič.

Zapuščena

K a milo M a š e k, glas, klavir, besedilo. - Slovenska gerlica VI/1859, str. 18-19, št. 15 .

B e n j a m i n I p a ve c, moški zbor, besedilo. - Benjamin in Gustav Ipavec: Slovenske pesme 1862, zv. 1, str. 5. - Lavorika I [1880], št. 38, zborovska garnitura. - Zbirka slovenskih napevov ubranih za četvero ali petero moških glasov, zv. VII/1880, str. 42-43. - Zbori, Pesmarica Glasbene matice. Uredil Josip Čerin. 1. izdaja, 1. in 2. natis 1897,3 . natis 1908, str. 169-170. - Opalografija [b. 1.] 1 str., $4^{0}$.

Ipavčev napev prirejen za ženski zbor. - Naši zbori 4//1949, sn. 1, str. 14. NUK Ms, Glasbena zbirka.

Poročilo: [Adolf Groebming] Gg, Naši zbori 4/1949, sn. 1 (III. ovoj. str.) o izreki pri izvajanju.

E m i 1 A d a mi č, moški zbor, besedilo. - Novi akordi 1/1901-1902, str. 88.

- Prešernov dan 1946, str. 41-43, hrvaška izdaja str. (50-52). — Sedem Prešernovih pesmi 1948, str. (8-10).

Poročilo: Anton Lajovic, Novi akordi 9/1910, zv. 3-4, str. 32; SN 43/1910 (10. 3.), št. 56, str. 2, analiza skladbe in o koncertu Glasbene matice v Ljubljani 9. 3. 1910. - [Emil Adamič], Novi akordi, glasbenoknjiž. pril. 9/1910, št. 6, str. 45, o sijajnem uspehu pevskega zbora in orkestra čitalnice pri sv. Jakobu $v$ Trstu 18. 9. 1910.

Zarjovena dvičica

Fra n $\mathrm{Oz}$ b i č, dvoglasno, klavir, besedilo. - Kres 3/1883, str. 379. 225

Komentar: J[akob] Sket, Kres 3/1883, str. 376-379, o napevu čeških harfistk, na katerega je Prešeren na Dunaju zložil slovensko pesem.

M a tij a Tom c, ženski zbor, besedilo. - Naši zbori 4/1949, sn. 2, str. 26-28.

Poročilo: [Adolf Groebming] Gg, Naši zbori 4/1949, sn. 2 (III. in IV. ovoj. str.), o trpkem in jedkem humorju skladbe in o izreki pri izvajanju.

Zdravljica

Davorin J e nko, petje, klavir, besedilo. - D. Jenko: Fr. Prešernove pesmi za petje $\mathrm{i}$ glasovir 1862, str. 6, št. 2. Op. 3. - D. Jenko: Samospevi z glasovirom [1880], št. 2. - D. Jenko: 18 slovenskih pesnij [1908], str. 17. 227

B e $\mathbf{n}$ j a $\mathbf{m}$ i n I p a ve c, samospev, moški zbor, klavir, besedilo. - Benjamin in Gustav Ipavec: „Napitnicac. Slovenske pesmi II [1864], str. 11-12. - »Trinklied爪. Slavische Blätter 1/1885, str. 414-416. Podloženo slovensko besedilo in nemški prevod Lujze Pesjakove. - Naši zbori 4/1949, sn. 5-6, str. 85-86. 228

Ocene: Vojteh Valenta, Slovan 9/1876 (3.12.), št. 278, str. 1-3, besedilu primeren mojstrski napev. - [Adolf Groebming] Gg, Naši zbori 4/1949 sn. 5-6 (II. in IV. ovoj. str.), sveža in lahko izvedljiva skladba, navodila za izvajanje.

Fran G e r bi č, moški zbor, besedilo. Op. 15. - F. Gerbič : Slovanska jeka [1880], str. $29-30$.

St a nko Premr1, mešani zbor, besedilo. - Novi akordi 5/1905-1906, št. 4, str. 48. - Pevčeva pesmarica. Uredil Fran Kimovec 1921, zv. 1, str. 20-21, 
št. 16. - Marko Bajuk: Pevska šola 1922, str. 110-111. — Slovenska pesem. Uredila A[nton] Dolinar in V[enceslav] Snoj 1944, zv. I, str. 92-94, št. 6. 33 moških in mešanih zboror [1946], str. 92-94, št. 6. - Prešernov dan 1946, str. 43-44, hrvatska izdaja str. (52-53). — Sedem Prešernovih pesmi 1948, str. 10-11. - Naši zbori $2 / 1947$ zv., str. 1 .

S t a n k o Premr l, moški zbor, besedilo. - Pevčeva pesmarica. Uredil Fran Kimovec 1921, str. 21-22, zv. 1. - Zbori. Pesmarica Glasbene matice, uredil po Čerinovi izdaji Matej Hubad. 2. izdaja, 1. natis 1922, 2. natis 1929, str. 137-138. - Pesmarica Glasbene matice, 3. izdaja I. zv. str. 170-171 = 27 moških zborov [1945], str. 170-171. - [Otmar Pelan] Pelot: Zbirka slovenskih priljubljenih pesmi II/1946, str. 108-110, št. 63. - Prešernov dan 1946, str. 36-37, hrvatska izdaja 1946, str. (45-46). - Sedem Prešernovih pesmi 1948, str. (3-4). - Opalografija 1955, 1 str., $4^{0}$.

Ocena : Fr[an] Zabret, Pevec, 1/1921, št. 5-6, str. 2-3, o Premrlovi Napitnici.

Premrlov napev za troglasni mladinski zbor priredil Luka Kramolc. Luka Kramolc: Pesem mladine 1944, str. 10.

Premrlov napev dvoglasno priredil Ivan Grbec. - Ivan Grbec, Pesmarica za osnovne, nižje, srednje in strokovne šole. I. del 1954, str. 126.

C h. G ro'zd ov, moški zbor, besedilo. - Novi akordi 9/1910, str. 11-12.

Podloženo je slovensko besedilo in Koršev ruski prevod.

Po Ch. Grozdovu [!] predelal in za mešani zbor priredil V a silij Mirk. Naši zbori 4/1949, sn. 4, str. 45-47.

Poročila: [Anton Aškerc], LZ 22/1902, str. 355, o Prešernovi odi v Rusiji. Fr[an] Ilešič, LZ 27/1907, str. 383 D. K. Popov je prevedel v bolgarščino 1., 2. in 4. kitico Zdravljice ter jo s skladbo Gvozdova objavil v Slavjanskem glasu 1907, št. 2. - [Gojmir Krek], Novi akordi, glasbenoknjiž. pril. 9/1910, št. 1, str. 6. Grozdov jo je uglasbil kot mnastolnuju pesnju(. Moški glasovi so deloma izdatno niže stavljeni, kakor je to pri nas navada, to pa je menda edino, kar je na skladbi ruskega. - [Adolf Groebming] Gg, Novi akordi 4/1949, št. 4 (II., III. in IV. ov. str.), o sodobnem licu Mirkove priredbe, navodila za izvajanje.

Vinko Vodopivec, moški zbor, besedilo. - Vinko Vodopivec: Mešani in moški zbori, Gorica 1923, str. 15-18, št. 9. 236

Makso Pirnik, triglasni mladinski zbor, besedilo. - Makso Pirnik: Pesmi za mladenke, izdelala tehnika v Slovenskem Primorju 1943, str. 30-31. - Izdelala Belokranjska tehnika aprila 1944, str. 6-7. - Makso Pirnik: V nove zarje 1946, str. 23-24, št. 18. - Opalografija 1954, 1 str., $4^{0}$.

M a k s o Pirnik, mešani zbor, besedilo. - Naši zbori 4/1949, sn. 1, str. o. - Makso Pirnik: Drobne pesmi 1953, zv. 1, str. 10-11. 238

Poročilo: [Adolf Groebming] Gg. Naši zbori 4/1949, sn. 1 (III. ov. str.), skladba je lahkega značaja in namenjena najširšemu krogu pevskih zborov, o izreki pri izvajanju. - NUK Ms Glasbena zbirka.

Ma k s o Pirnik, dvoglasno, besedilo. - Zapojmo. Pesmarica za III. in IV. razred osnovnih šol. Izbrala in uredila Slavko Mihelčič in Peter Potočnik. 1949, str. 5-6, št. 4 .

Va si lij Mirk : Himna. Mešani zbori. - Vasilij Mirk: Skladbe za mešani zbor 1946, str. 5-6.

Rokopis last avtorja. - Skladba na kitici »Edinost, sreča, sprava( in »Žive naj vsi narodic. 
Danilo Śvara : Trije spevi iz opere »Prešeren« za tenor in klavir. 1. Okusil zgodaj sem tvoj sad, 2. V srce mi padla iskra je ognjena, 3. Magistrale, Ljubljana, opalografija 1954, 11 str., $4^{\circ}$.

Danilo Śvara : Dva speva iz opere »Prešeren« za sopran in klavir. 1. Oči sem večkrat vprašal, 2. Mirno so tekla. Ljubljana, opalografija 1954, 11 str. $4^{0} . \quad 257$

Rado Simoniti : Pesniku Prešernu. »Tudi mi, učenci mladi.« Iz Cicibana. Mladinski zbor. Za Prešernove proslave v osnovnih šolah. - Rado Simoniti: Zbirka otroških in mladinskih zborov 1957, str. 26.

\section{SUMMARY}

The musical material, dating from the period 1846-1963, has been divided into three sections: I. Collections of printed music devoted exclusively to settings of the poems of Prešeren. These collections are listed in chronological order. II. Prešeren's Poems. The titles are listed in alphabetical order and the composers who made settings of the poems are given in chronological order, according to the date of publication. III. Compositions written in honour of Prešeren, also listed in chronological order.

The first appearance in print and the first musical settings or arrangements of these poems constitute and independant bibliographical section. The listings of the compositions are accompanied by newspaper reviews and criticisms of their performances. The place of preservation of the musical manuscripts is also indicated.

The musical material and explanations have been obtained from the music collection of the National and University Library, the Library of the Music Academy and the archives of the Slovene Philharmonia as well as from the composers themselves. 